\title{
Non-Invasive Monitoring Based on Bioreactance Reveals Significant Hemodynamic Instability during Elective Cesarean Delivery under Spinal Anesthesia
}

\author{
Anne Doherty ${ }^{1}$, Yayoi Ohashi ${ }^{2}$, Kristi Downey ${ }^{3}$, Jose CA Carvalho ${ }^{4}$
}

\begin{abstract}
Doherty A, Ohashi Y, Downey K, Carvalho JCA - Non-Invasive Monitoring Based on Bioreactance Reveals Significant Hemodynamic Instability during Elective Cesarean Delivery under Spinal Anesthesia.

Background and objectives: Blood pressure monitoring offers a limited understanding of the hemodynamic consequences of spinal anesthesia for cesarean delivery. The purpose of this study was to assess, with the aid of a non-invasive cardiac output monitor based on bioreactance, the hemodynamic changes during elective cesarean delivery under spinal anesthesia in which intermittent boluses of phenylephrine were used to prevent and treat hypotension.
\end{abstract}

Methods: This observational study was conducted with the Research Ethics Board approval, and all participants provided written informed consent. Healthy patients undergoing elective cesarean delivery under spinal anesthesia were enrolled. Intermittent boluses of phenylephrine were administered in an attempt to maintain systolic blood pressure at baseline levels, and patients were assessed with a non-invasive cardiac output monitor based on bioreactance. Hemodynamic data was collected continuously at baseline, and during the postspinal and postdelivery periods. Data was analyzed using a mixed model ANOVA, and a $\mathrm{p}<0.05$ was considered significant.

Results: Systolic blood pressure was maintained within $79.2 \pm 14.2$ and $105.8 \pm 10.0$ percent of baseline during the postspinal period, and $78.4 \pm 11.3$ and $100.9 \pm 10.7$ percent of baseline in the postdelivery period (mean \pm SD) There were significant fluctuations in systolic blood pressure, heart rate, and cardiac output during the postspinal period, and significant fluctuations in systolic blood pressure and cardiac output in the postdelivery period.

Conclusions: A new non-invasive monitor based on bioreactance reveals significant hemodynamic fluctuations during cesarean delivery under spinal anesthesia, despite attempts to maintain blood pressure at baseline levels with intermittent boluses of phenylephrine.

Keywords: Anesthesia, Obstetrical, Spinal; Cesarean Section; Hemodynamics Monitoring, Bioreactance.

Financial Support: Equipment for the study was provided by Cheetah Medical Inc. The company had no involvement in the study design, data interpretation, or manuscript preparation.

[Rev Bras Anestesiol 2011;61(3): 320-332] @Elsevier Editora Ltda.

\section{INTRODUCTION}

Hypotension during cesarean delivery under spinal anesthesia may occur in up to $80 \%$ of patients if prophylactic measures are not taken ${ }^{1,2}$. The etiology of hypotension during cesarean delivery is multifactorial, but it is primarily determined by a decrease in cardiac output (CO) as a result of decreased

Received from Department of Anesthesia and Pain Management, Mount Sinai Hospital, University of Toronto, Canada.

1. MD; Obstetric Anesthesia Fellow, Department of Anesthesia and Pain Management, Mount Sinai Hospital, University of Toronto

2. MD, PhD; Obstetric Anesthesia Fellow, Department of Anesthesia and Pain Management, Mount Sinai Hospital, University of Toronto

3. MSc; Perinatal Anesthesia Research Coordinator, Department of Anesthesia and Pain Management, Mount Sinai Hospital, University of Toronto

4. MD, PhD, FANZCA, FRCPC; Professor of Anesthesia and Obstetrics and Gynecology,

Director of Obstetric Anesthesia, Mount Sinai Hospital, University of Toronto

Submitted on November 30, 2010.

Approved on December 7, 2010.

Correspondence to:

Jose CA Carvalho, MD, PhD

Department of Anesthesia and Pain Management

Mount Sinai Hospital

600 University Avenue, Room 781

Toronto, Ontario, M5G 1 X5, Canada

E-mail: Jose.Carvalho@uhn.on.ca preload, and/or a decrease in systemic vascular resistance (SVR) from a spinal-induced sympathetic blockade. Drugs such as vasoconstrictors, nitroglycerin and oxytocin used intra-operatively may further alter maternal blood pressure ${ }^{3,4}$. Several strategies for the prevention and treatment of hypotension have been suggested, such as fluid co-loading and the administration of vasoconstrictors ${ }^{5}$. Current evidence supports the maintenance of maternal systolic blood pressure (SBP) at baseline throughout the procedure, and also suggests that phenylephrine is the vasoconstrictor of choice for the management of spinal-induced hypotension during cesarean delivery ${ }^{6,7}$. Formerly limited to intermittent assessment of blood pressure, the introduction of minimally invasive and non-invasive cardiac output monitoring devices has enabled a better understanding of the hemodynamic changes occurring during cesarean delivery. Rapid changes in $\mathrm{CO}$ and SVR have been demonstrated immediately after intrathecal injection and in the postdelivery period ${ }^{8,9}$. It would be ideal to have the benefit of a complete hemodynamic profile of each individual patient throughout the procedure. This is only likely to happen in obstetric patients with the aid of a non-invasive, operator-independent, user-friendly monitoring device. 
Bioreactance ${ }^{\circledR}$ technology is a new technique of non-invasive continuous cardiac output monitoring. It is based on the analysis of the relative phase shifts of oscillating currents that occur when the current traverses the thoracic cavity, as opposed to the traditional bioimpedance-based system, which relies only on measured changes in the signal amplitude ${ }^{10}$.

The purpose of this study was to assess, with the aid of a non-invasive cardiac output monitor based on bioreactance, the hemodynamic changes during elective cesarean delivery under spinal anesthesia, in which intermittent boluses of phenylephrine were used to prevent and treat hypotension.

\section{METHODS}

This observational study was conducted with the Research Ethics Board approval, and was registered with the clinicaltrials.gov protocol registration system (NCT00949260). All patients presenting for elective cesarean delivery of a normal singleton fetus under spinal anesthesia were considered for the study. All patients recruited provided written informed consent, were ASA I/II and over 18 years of age. Exclusion criteria were: weight $<50 \mathrm{~kg}$ or $>100 \mathrm{~kg}$, height $<150 \mathrm{~cm}$ or $>180 \mathrm{~cm}$, pre-existing or pregnancy-induced hypertension, cardiovascular or cerebrovascular disease, a history of diabetes (excluding gestational diabetes) or contra-indications for spinal anesthesia.

Upon arrival in the operating room, the patient was placed supine and slightly tilted to the left to avoid aorto-caval compression. Hemodynamic information was gathered using a bioreactance-based non-invasive cardiac output monitoring system (NICOM ${ }^{\circledR}$, Cheetah Medical Inc, Portland, Oregon, USA). The baseline systolic blood pressure was measured by averaging three readings taken one minute apart using an automated non-invasive blood pressure monitor. Four NICOM ${ }^{\circledR}$ electrodes were placed, two below the clavicle in the midclavicular line, and two at the costal margin in the mid-clavicular line. The monitoring system was then allowed to calibrate. Patients were co-loaded with $10 \mathrm{~mL} . \mathrm{kg}^{-1}$ of Ringer's Lactate, and spinal anesthesia was performed in the sitting position, at $\mathrm{L}_{3}-\mathrm{L}_{4}$, with hyperbaric bupivacaine $0.75 \% 1.8 \mathrm{~mL}, 10 \mu \mathrm{g}$ of fentanyl and $100 \mu \mathrm{g}$ of morphine. After the intrathecal injection, the patient was positioned supine, with left uterine displacement using a wedge under the right hip. Pulse oximetry and hemodynamic data were recorded continuously, and included heart rate (HR), stroke volume (SV), cardiac output (CO), total peripheral resistance (TPR), and thoracic fluid content (TFC). Systolic blood pressure (SBP) was assessed every minute. The attending anesthesiologist administered the anesthetic in the usual manner, aiming to preserve maternal SBP at $100 \%$ of baseline using vasoconstrictors or anti-cholinergics at their own discretion. The standard practice at our institution is the use of intermittent $100 \mu \mathrm{g}$ boluses of phenylephrine whenever the SBP is below control values. Ephedrine in boluses of $5 \mathrm{mg}$ is only used if the heart rate is persistently $<50 \mathrm{bpm}$.

Upon delivery, a segment of the umbilical cord was collected for blood gas assessment in both the umbilical artery and vein. Oxytocin was administered as a bolus of $0.5 \mathrm{IU}$ over 5 seconds upon delivery of the anterior fetal shoulder, followed by an infusion of $40 \mathrm{mU} \cdot \mathrm{min}^{-1}$, (20 IU oxytocin added to $1.000 \mathrm{~mL} \mathrm{LR}$ at the rate of $120 \mathrm{~mL}^{-1} \mathrm{~h}^{-1}$ ). Additional boluses of oxytocin were used if requested by the attending obstetrician. Any other medications were administered as per the obstetricians' requests.

Hemodynamic monitoring using $\mathrm{NICOM}^{\circledR}$ was performed throughout the procedure. This was commenced prior to the intrathecal injection, and continued until 10 minutes after delivery of the fetus.

The primary outcome was the hemodynamic changes over time in the postspinal and postdelivery periods.

Additional data collected included maternal age, weight and height, the time of intrathecal injection and delivery, the upper sensory level of anesthesia on delivery, the time and amount administered of medications acting on the cardiovascular system, and the umbilical artery and vein blood gases obtained on delivery.

Data analysis consisted of 3 phases: control, postspinal, and postdelivery. The control phase consisted of a three-minute period prior to the intrathecal injection with the patient in the supine wedged position; the spinal phase consisted of the ten minutes immediately after intrathecal injection; and the delivery phase consisted of the ten minutes after delivery of the fetus.

Separate analyses were performed for each phase. For all variables, the design was a repeated measure over time (minutes). A mixed model ANOVA for repeated measures was used to analyze data using the Mixed Procedure in SAS 9.1. Since there was no a priori correlation between the times for the variables, two types of correlation structures were considered. These were compound symmetry (CS) and auto correlation of lag 1, AR. ${ }^{1}$ The former correlation structure assumed a constant correlation between all time points. The latter assumed a correlation that decreased over time, so that observations further apart were assumed to have a smaller correlation than the ones closer to each other in time. Since the measurements were only a minute apart, these two structures were seen to give very similar results. The Akaike Information Criterion (AIC) correlation was used to assess the statistical models, and structures that had a smaller AIC were used.

Time was the main effect analyzed, and the linear and quadratic functions of time were modeled. A quadratic effect was first modeled. The quadratic model necessarily included the linear effect. If the quadratic effect was not significant $(p>0.05)$, it was removed. The linear effect was then tested at the same significance level. If there was also no linear effect, then it was concluded that there was no evidence that the variable changed over time. A convenience sample size of 20 women was used.

\section{RESULTS}

Thirty women were approached to participate in the study between November 2009 and January 2010. Of these, 24 consented to take part. The reasons given for non-participation were that they had no interest in taking part in research studies, had agreed to another study or wanted standard 
Table I - Mean Values of Hemodynamic Variables in Each Studied Period

\begin{tabular}{llll}
\hline & Control & Post Spinal & Post Delivery \\
& $\mathrm{n}=20$ & $\mathrm{n}=20$ & $\mathrm{n}=20$ \\
\hline CO $($ L.min & -1 & $7.0(1.2)$ \\
HR $(\mathrm{bpm})$ & $7.0(1.3)$ & $6.7(1.1)$ & $78.1(11.7)$ \\
SBP $(\mathrm{mmHg})$ & $80.9(12.0)$ & $81.4(11.6)$ & $107.7(12.1)$ \\
TPR $($ dyne.s.cm & -5 & $111.6(11.5)$ & $928.7(212.2)$ \\
SV $(\mathrm{mL})$ & $120.9(10.7)$ & $1016.6(133.5)$ & $90.2(18.5)$ \\
TFC $($ L.kOhm & $1128.6(226.6)$ & $84.5(17.6)$ & $82.0(13.8)$ \\
\hline
\end{tabular}

Results and mean (SD); CO: cardiac output; HR: heart rate; SBP: systolic blood pressure; TPR: total peripheral resistance; SV: stroke volume: TFC: thoracic fluid content.

monitoring. Of the consented women, one changed her mind on arrival in the operating room, two weighed $>100 \mathrm{~kg}$ on the day of surgery and one was moved to another operating room for surgery. Twenty women were included in the analysis.

The women were $35.5 \pm 5.1 \mathrm{yr}, 79.8 \pm 13.0 \mathrm{~kg}, 162.3 \pm$ $6.2 \mathrm{~cm}, 30.2 \pm 4.1 \mathrm{~kg} \cdot \mathrm{m}^{-2}$, (mean $\pm \mathrm{SD}$ ).

Baseline hemodynamic assessment revealed very diverse individual hemodynamic profiles. Cardiac output ranged from 4.4 L. $\mathrm{min}^{-1}$ to 9.4 L.min-1 , HR from 58 to $107 \mathrm{bpm}$, SV from 47.5 to $128.2 \mathrm{~mL}$, TPR from 750 to 1646 dyne.s.cm ${ }^{-5}$, SBP from 102 to $147 \mathrm{mmHg}$, and TFC from 50.8 to $109.2 \mathrm{~L} / \mathrm{kOhm}^{-1}$.

The mean values for each of the hemodynamic variables during the control and each of the study periods are shown in Table I. There were no significant differences in the mean values of hemodynamic variables between the control values and postspinal and postdelivery periods.

The mean values for maximum percentage increase and decrease for each of the hemodynamic variables assessed, during each study period, are shown in Table II. Systolic blood pres-

Table II - Maximum and Minimum Percent Changes in Hemodynamic Variables during Postspinal and Postdelivery Period

\begin{tabular}{|c|c|c|}
\hline & $\begin{array}{l}\text { Post Spinal } \\
\mathrm{n}=20\end{array}$ & $\begin{array}{l}\text { Post Delivery } \\
\mathrm{n}=20\end{array}$ \\
\hline \multicolumn{3}{|l|}{$\mathrm{CO}\left(\right.$ L. $\left.\mathrm{min}^{-1}\right)$} \\
\hline Maximum \% & $111.0(11.0)$ & 113.6 (16.5) \\
\hline Minimum \% & $84.6(13.0)$ & $87.6(13.6)$ \\
\hline \multicolumn{3}{|l|}{$\mathrm{HR}$ (bpm) } \\
\hline Maximum \% & $118.9(14.7)$ & $103.9(12.8)$ \\
\hline Minimum \% & $76.2(9.6)$ & $88.6(11.3)$ \\
\hline \multicolumn{3}{|l|}{$\mathrm{SBP}(\mathrm{mmHg})$} \\
\hline Maximum \% & $105.8(10.0)$ & $100.9(10.7)$ \\
\hline Minimum \% & $79.2(14.2)$ & $78.4(11.3)$ \\
\hline \multicolumn{3}{|c|}{ TPR (dyne.s.cm-5) } \\
\hline Maximum \% & $113.0(16.2)$ & $100.2(18.3)$ \\
\hline Minimum \% & $77.0(9.7)$ & $71.2(11.0)$ \\
\hline \multicolumn{3}{|l|}{$\mathrm{SV}(\mathrm{mL})$} \\
\hline Maximum \% & $111.0(16.1)$ & 115.1 (16.7) \\
\hline Minimum \% & $84.0(9.4)$ & $93.4(10.8)$ \\
\hline \multicolumn{3}{|l|}{ TFC (L.kOhm-1) } \\
\hline Maximum \% & $99.9(4.9)$ & $98.5(4.1)$ \\
\hline Minimum \% & $95.2(3.9)$ & $94.0(3.8)$ \\
\hline
\end{tabular}

Results and mean (SD); CO: cardiac output; HR: heart rate; SBP: systolic blood pressure; TPR: total peripheral resistance; SV: stroke volume: TFC: thoracic fluid content. sure was maintained within $79.2 \pm 14.2$ and $105.8 \pm 10.0$ percent of baseline during the postspinal period, and $78.4 \pm 11.3$ and $100.9 \pm 10.7$ percent of baseline in the postdelivery period.

While the mean values were not significantly different between the control and study periods, the ANOVA analysis revealed significant fluctuations over time in $\mathrm{CO}, \mathrm{SBP}$, and HR during the postspinal period (Table III). There were also significant fluctuations in $\mathrm{CO}$ and SBP during the postdelivery period. The hemodynamic trends which fluctuated significantly over time are shown in Figures 1-5; in contrast, Figure 6 shows the individual HR trend with smoother during the post-

Table III - $p$ Values from ANOVA Analysis of Intra-Patient and Inter-Patient Variability from the Mean with Respect to Time

\begin{tabular}{|c|c|c|c|}
\hline Variable & $\begin{array}{l}\text { Control } \\
p\end{array}$ & $\begin{array}{l}\text { Post-Spinal } \\
\mathrm{p}\end{array}$ & $\begin{array}{l}\text { Post Delivery } \\
\mathrm{p}\end{array}$ \\
\hline $\mathrm{CO}\left(\mathrm{L} . \mathrm{min}^{-1}\right)$ & 0.9846 & $<0.0001$ * & 0.0003 * \\
\hline $\mathrm{SBP}(\mathrm{mmHg})$ & 0.8075 & 0.0115 * & 0.0095 * \\
\hline $\mathrm{HR}$ (bpm) & 0.7062 & $0.0005^{*}$ & 0.1154 \\
\hline TPR (dyne.s.cm ${ }^{-5}$ ) & 0.9393 & 0.8430 & 0.1421 \\
\hline $\mathrm{SV}(\mathrm{mL})$ & 0.6495 & 0.1941 & 0.2106 \\
\hline TFC (L.kOhm $\left.{ }^{-1}\right)$ & 0.6916 & 0.1400 & 0.9456 \\
\hline
\end{tabular}

CO: cardiac output; HR: heart rate; SBP: systolic blood pressure; TPR: total peripheral resistance; SV: stroke volume: TFC: thoracic fluid content.

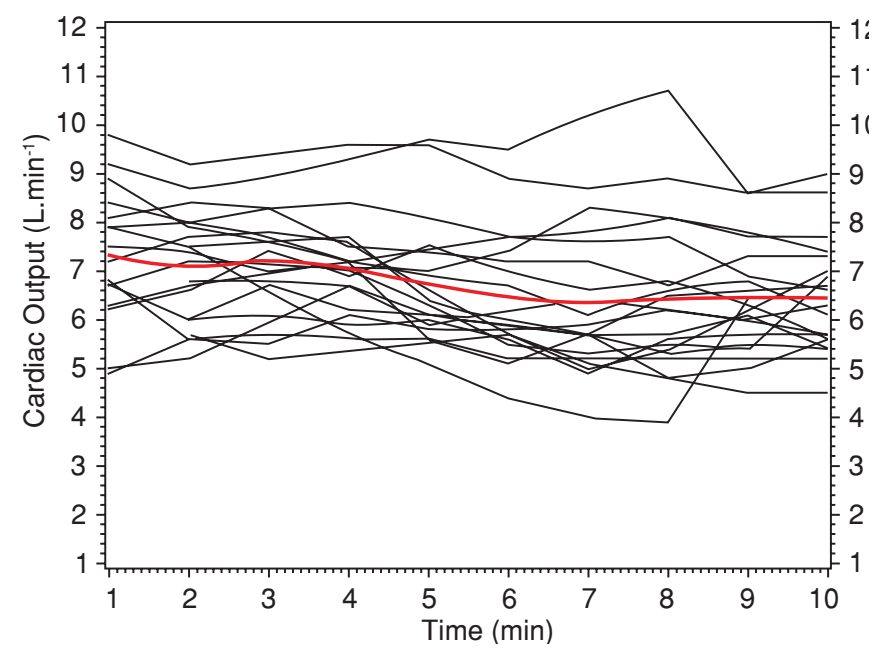

Figure 1 - Cardiac Output over Time during the Postspinal Period. 


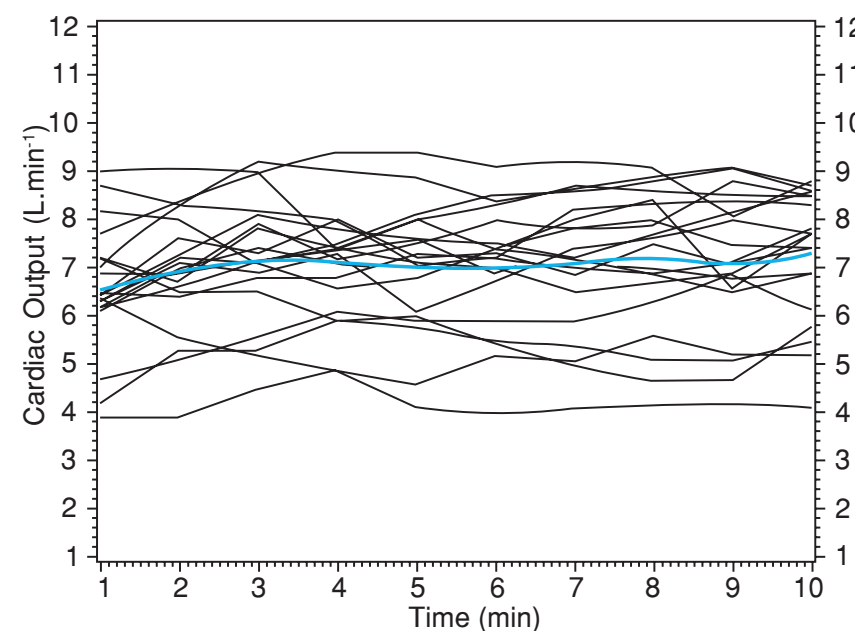

Figure 2 - Cardiac Output over Time during the Postdelivery Period.

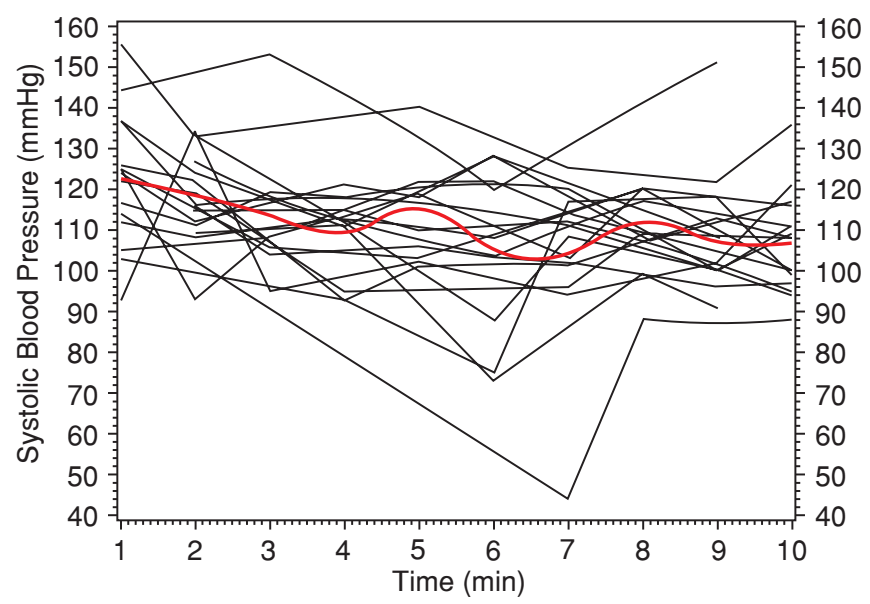

Figure 3 - Systolic Blood Pressure over Time during the Postspinal Period.

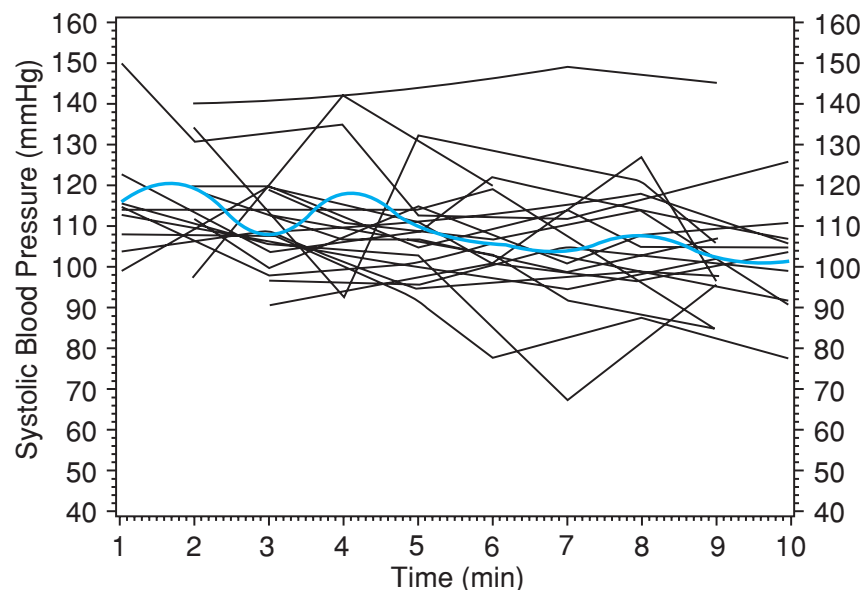

Figure 4 - Systolic Blood Pressure over Time during the Postdelivery Period.

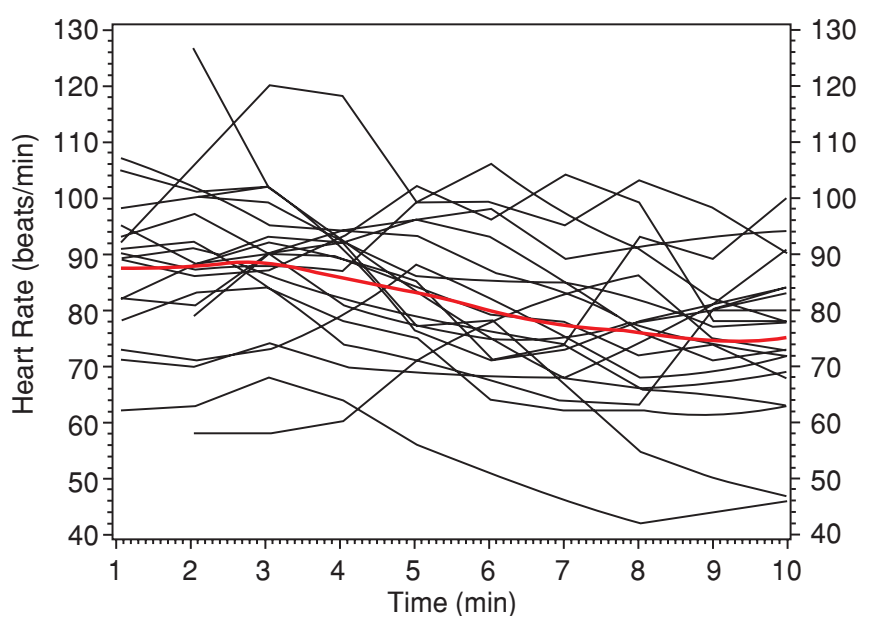

Figure 5 - Heart Rate over Time during the Postspinal Period.

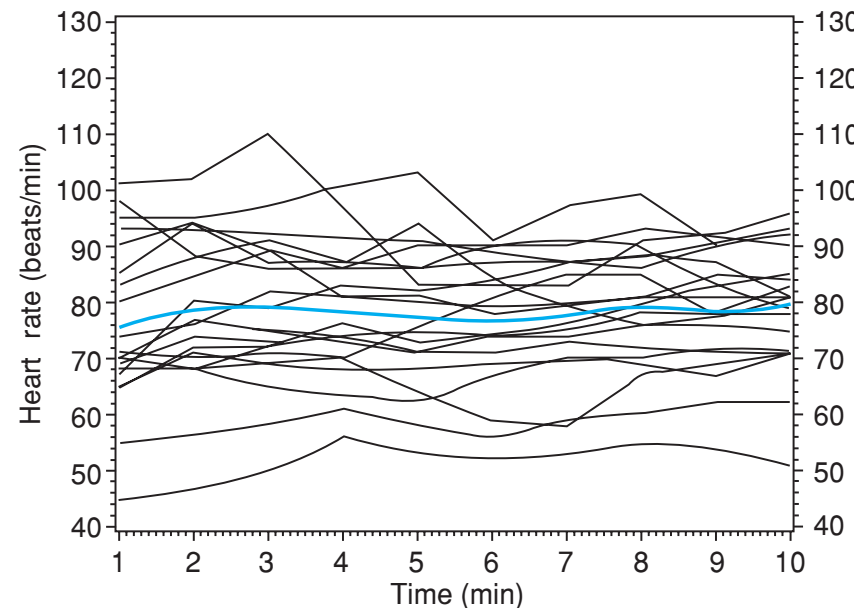

Figure 6 - Heart Rate over Time during the Postdelivery Period.

delivery period, which did not show significant intra-patient or inter-patient variability on analysis.

The amount of phenylephrine administered during the postspinal and postdelivery periods was $250 \pm 131.8$ and 205 $\pm 163.8 \mu \mathrm{g}$, respectively. The amount of ephedrine administered during the postspinal period was $1.3 \pm 2.2 \mathrm{mg}$. There was no ephedrine administered during the postdelivery period. Two women received atropine $600 \mu \mathrm{g}$ secondary to bradycardia during the postspinal period. One woman received two boluses of nitroglycerin $100 \mu \mathrm{g}$ immediately prior to delivery at the request of the attending obstetrician. The block level at the time of delivery, assessed by pin prick, was between T2 and T4 for all patients.

Arterial and venous umbilical blood samples were within normal range. The mean umbilical artery $\mathrm{pH}$ was $7.30 \pm 0.04$, with a mean arterial $\mathrm{CO}_{2}$ of $55.5 \pm 6.26 \mathrm{mmHg}$, and mean arterial base excess of $-1.56 \pm 1.29 \mathrm{mmol} . \mathrm{L}^{-1}$. The mean umbilical vein $\mathrm{pH}$ was $7.33 \pm 0.05$, with a mean venous $\mathrm{CO}_{2}$ of $49.05 \pm 8.46 \mathrm{mmHg}$, and mean venous base excess of $-1.08 \pm 1.32 \mathrm{mmol} . \mathrm{L}^{-1}$. 


\section{DISCUSSION}

The first important finding of this study is that we were able to demonstrate very diverse hemodynamic profiles in pregnant women at term through the use of a non-invasive, userfriendly, operator-independent monitor. This may introduce a new era of individualized patient assessment and anesthetic management, without relying on mean values for a cohort which is especially unsuitable in the obstetric population. The baseline cardiac output ranged from 4.4 to 9.4 L. $\mathrm{min}^{-1}$, making it clear that a mean value for cardiac output is perhaps irrelevant in clinical setting. This widely variable cardiac output in healthy term pregnant women has been previously documented using both Doppler ultrasound and impedance technology 11,12. A high resting heart rate at term was also seen. The total peripheral resistance showed values that are similar to the non-pregnant state. This has also been noted previously, disproving the usual assumption that low systemic vascular resistance persists throughout pregnancy to term ${ }^{13}$. In fact, our group has recently demonstrated with the same technology that healthy pregnant women at term have a very similar hemodynamic profile when compared to non-pregnant women ${ }^{14}$. This should have significant implications for teaching and understanding clinical practice in the near future.

The second important finding of our study is that there are significant fluctuations in cardiac output in postspinal period. The rapid changes in cardiac output in our patients were likely due to fluctuations in heart rate, as stroke volume did not vary significantly and total vascular resistance was maintained. A strong correlation between heart rate and cardiac output has been documented previously ${ }^{15}$. The rapid variation in heart rate was most likely due to the intermittent boluses of phenylephrine given to treat decreases in maternal systolic blood pressure. There was also no significant change in thoracic fluid content, indicating that there was no significant decrease in preload.

Our results differ from those of Langesaeter et al. ${ }^{9}$ and Dyer et al. ${ }^{15}$, who have documented a significant increase in cardiac output in the postspinal period followed by a significant decrease subsequent to vasoconstrictor administration. The difference between our results and their results may be explained by differences in the vasoconstrictor regimen used, and by the management of hypotension. Particularly, the trigger for vasoconstrictor administration in their studies was a fall in mean arterial pressure to $80 \%$ of baseline value. Also, Langesaeter et al. ${ }^{9}$ used low-dose phenylephrine infusion $\left(0.25 \mu \mathrm{g} \cdot \mathrm{kg}^{-1} \cdot \mathrm{min}^{-1}\right)$, and Dyer et al. ${ }^{15}$ used $80 \mu \mathrm{g}$ intermittent bolus doses, which are much lower than the doses used in our study. It is also important to note that Langesaeter et al. ${ }^{9}$ and Dyer et al. ${ }^{15}$ have used different technologies for hemodynamic monitoring, which may also explain some differences in our findings.

Our findings suggest that we may now be able to review our current practices, and that in general, there is no such a thing as a typical hemodynamic profile during spinal anesthesia for cesarean delivery. The response of a patient to the anesthetic is unique and dependent on the baseline hemodynamics, the anesthetic technique, and the type and regimen of vasoconstrictor administration. Although one may argue that comfortable patients and vigorous neonates are good enough outcomes, we may be able to design better plans, and even individualize care; this is especially important in high-risk women and fetuses, situations in which tailored regimens may prove safer and superior.

Current evidence suggests that maintenance of maternal SBP at $100 \%$ of baseline results in fewer adverse maternal symptoms and excellent fetal outcomes ${ }^{7}$. At our institution the treatment of any recorded fall in the maternal SBP from baseline is encouraged, and phenylephrine is the first line vasoconstrictor used. The ED 95 of intermittent phenylephrine boluses to prevent hypotension is quoted as at least $120 \mu \mathrm{g}$ per bolus ${ }^{16}$, however, in our institution a convenience dose of $100 \mu \mathrm{g}$ is still routinely used. In this observational study, the attending anesthesiologist was free to manage patient's SBP as per their usual practice. Despite the goal of maintaining SBP at baseline values the mean SPB for the group during the spinal period was maintained between $78 \%$ and $112 \%$ of baseline. The early treatment of any fall in maternal SBP using phenylephrine boluses may explain the immediate and rapid fluctuations in cardiac output and heart rate seen in this study. Maternal SBP was maintained at acceptable levels on means assessment, but showed significant fluctuations around the mean. This data suggest that one should either adhere to an all-or-nothing approach to the treatment of any fall in blood pressure, or perhaps consider a phenylephrine infusion regimen, should a more stable hemodynamic profile be desired. Additionally, if the intermittent bolus dose is the technique of choice, the bolus dose of phenylephrine should be increased, as discussed above.

Another interesting aspect of this study is that it realistically demonstrates the option of stabilizing intraoperative hemodynamics in cesarean deliveries by addressing the exact mechanisms of decompensation. The fall in cardiac output in our patients was primarily due to the fall in heart rate, due to the reflex bradycardia associated with phenylephrine administration. Thomas et al. studied the effects of phenylephrine and ephedrine on maternal cardiac output using cross-sectional and Doppler echocardiography ${ }^{17}$. Bradycardia secondary to phenylephrine administration was treated with atropine in 11 of 19 patients, and as a result the decreases in cardiac output were comparable to those with ephedrine administration. It is possible that pre-medicating patients with an anti-cholinergic may result in fewer hemodynamic fluctuations. Glycopyrrolate pre-medication could be considered advantageous, as it does not cross the placenta and may avoid adverse fetal effects. Maintaining maternal heart rate may also decrease the dose of phenylephrine required to maintain maternal blood pressure. However, this hypothesis requires further study.

Our results also show that the hemodynamic status of our patients was associated with vigorous neonates. Phenylephrine is suggested as the vasoconstrictor of choice in obstetric anesthesia due to better fetal umbilical gas profiles, as compared with ephedrine 6 . Ephedrine crosses the placenta, and may result in $\beta$-adrenergic receptor activation and an increased fetal metabolic rate. The superior fetal umbilical gas results, in spite of decreased cardiac output due to phenyleph- 
rine as compared to ephedrine administration, may be due to selective perfusion of the low resistance uteroplacental vascular bed.

Finally, our results also showed significant hemodynamic fluctuations in the postdelivery time, but again, unique to our anesthetic management. The hemodynamic effects of oxytocin bolus and infusion are well-documented. Oxytocin receptors are widely present in the cardiovascular system ${ }^{18}$. The activation of oxytocin receptors in the heart releases atrial natriuretic peptide; on the endothelial receptors, it stimulates the release of nitric oxide ${ }^{17}$. As a result, vasodilation is observed. Increased cardiac output and heart rate in the postdelivery period usually occur as a response to a fall in vascular resistance due to oxytocin administration. In this study, this response was blunted by the administration of phenylephrine, and a much less-pronounced effect was observed. This effect has previously been noted by Dyer et al. ${ }^{15}$.

Hemodynamic assessment during cesarean deliveries in clinical practice is currently by and large limited to blood pressure and heart rate assessment. However, hemodynamic changes during cesarean delivery have been assessed through a variety of different methods, including thoracic ${ }^{15}$ and whole body impedance ${ }^{8}$, echocardiography and Doppler ultrasound ${ }^{19}$, all minimally invasive techniques ${ }^{9}$, as well as pulmonary artery catheterization and thermodilution. All of these methods have limitations, and are unlikely to become routine clinical practice especially as bedside monitoring techniques.

Bioreactance technology is a newer form of non-invasive continuous cardiac output monitoring ${ }^{10,14}$, and has recently been used in the obstetric population for the first time ${ }^{14}$. It is based on an analysis of the relative phase shifts of oscillating currents that occur when the current traverses the thoracic cavity, as opposed to the traditional bioimpedance-based system which relies only on measured changes in signal amplitude. Unlike bioimpedance, bioreactance-based non-invasive $\mathrm{CO}$ measurement does not use static impedance, and does not depend on the distance between the electrodes for SV and $\mathrm{CO}$ calculations, thereby significantly increasing the accuracy of the result. Moreover, its readings were shown to correlate well with results obtained from the pulmonary artery catheter thermodilution-derived measurements of cardiac output ${ }^{10}$. In addition, it has also been shown that the $\mathrm{NICOM}^{\circledR}$ system has acceptable accuracy, precision and responsiveness for $\mathrm{CO}$ monitoring in patients experiencing a wide range of circulatory situations ${ }^{20}$. Important features of this technology are that it is completely non-invasive and operator-independent.

In summary, we report for the first time the use of a noninvasive monitor based on bioreactance for assessment of hemodynamic changes during spinal anesthesia for cesarean delivery. We were able to obtain continuous hemodynamic data with clear and consistent signals, and we identified a very diverse hemodynamic profile in pregnant women at term. Furthermore, we identified rapid hemodynamic fluctuations associated with the anesthetic technique, patient positioning, delivery of the fetus, and vasoactive drugs including vasoconstrictors and oxytocin. We suggest that comprehensive non-invasive, operator-independent, continuous bedside hemodynamic monitoring may contribute to the individualized care of patients, and to the improvement of the anesthetic management in obstetrics. 


\section{REFERÊNCIAS / REFERENCES}

01. Clark RB, Thompson DS, Thompson CH - Prevention of spinal hypotension associated with Cesarean section. Anesthesiology, 1976;45:670-674.

02. Macarthur A, Riley ET - Obstetric anesthesia controversies: vasopressor choice for postspinal hypotension during cesarean delivery. Int Anesthesiol Clin, 2007;45:115-132.

03. Pinder $A J$, Dresner $M$, Calow $C$ et al. - Haemodynamic changes caused by oxytocin during caesarean section under spinal anaesthesia. Int J Obstet Anesth, 2002;11:156-159. 
04. Langesaeter E, Rosseland LA, Stubhaug A - Hemodynamic effects of oxytocin during cesarean delivery. Int J Gynaecol Obstet, 2006;95:46-47.

05. Cyna AM, Andrew M, Emmett RS et al. - Techniques for preventing hypotension during spinal anaesthesia for caesarean section. Cochrane Database Syst Rev, 2006;(4):CD002251.

06. Ngan Kee WD, Khaw KS, Ng FF - Comparison of phenylephrine infusion regimens for maintaining maternal blood pressure during spinal anaesthesia for Caesarean section. Br J Anaesth, 2004;92:469-474.

07. Ngan Kee WD, Khaw KS, Tan PE et al. - Placental transfer and fetal metabolic effects of phenylephrine and ephedrine during spinal anesthesia for cesarean delivery. Anesthesiology, 2009;111:506-512.

08. Tihtonen K, Koobi T, Yli-Hankala A et al. - Maternal hemodynamics during cesarean delivery assessed by whole-body impedance cardiography. Acta Obstet Gynecol Scand, 2005;84:355-361.

09. Langesaeter $E$, Rosseland LA, Stubhaug A - Continuous invasive blood pressure and cardiac output monitoring during cesarean delivery: a randomized, double-blind comparison of low-dose versus highdose spinal anesthesia with intravenous phenylephrine or placebo infusion. Anesthesiology, 2008;109:856-863.

10. Keren $H$, Burkhoff $D$, Squara $P$ - Evaluation of a noninvasive continuous cardiac output monitoring system based on thoracic bioreactance. Am J Physiol Heart Circ Physiol. 2007;293:H583-H589.

11. van Oppen AC, Stigter RH, Bruinse HW - Cardiac output in normal pregnancy: a critical review. Obstet Gynecol, 1996;87:310-318.

12. Dennis $A$, Arhanghelschi I, Simmons $S$ et al. - Prospective observational study of serial cardiac output by transthoracic echocardiography in healthy pregnant women undergoing elective caesarean delivery. Int J Obstet Anesth, 2010;19:142-148.

13. Moertl MG, Ulrich D, Pickel KI et al. - Changes in haemodynamic and autonomous nervous system parameters measured non-invasively throughout normal pregnancy. Eur J Obstet Gynecol Reprod Biol. 2009;144(Suppl 1):S179-S183.

14. Ohashi $Y$, Ibrahim H, Furtado L et al. - Non-invasive hemodynamic assessment of non-pregnant healthy pregnant and preeclamptic women using bioreactance. Rev Bras Anestesiol, 2010;60:603-613.

15. Dyer RA, Reed AR, van Dyk $D$ et al. - Hemodynamic effects of ephedrine, phenylephrine, and the coadministration of phenylephrine with oxytocin during spinal anesthesia for elective cesarean delivery. Anesthesiology, 2009;111:753-765.

16. Tanaka M, Balki M, Parkes RK eet al. - ED95 of phenylephrine to prevent spinal-induced hypotension and/or nausea at elective cesarean delivery. Int J Obstet Anesth, 2009;18:125-130.

17. Gutkowska J, Jankowski M, Mukaddam-Daher $S$ et al. - Oxytocin is a cardiovascular hormone. Braz J Med Biol Res, 2000;33:625-633.

18. Thibonnier M, Conarty DM, Preston JA et al. - Human vascular endothelial cells express oxytocin receptors. Endocrinology, 1999;140:1301-1309.

19. Thomas DG, Robson SC, Redfern $\mathrm{N}$ et al. - Randomized trial of bolus phenylephrine or ephedrine for maintenance of arterial pressure during spinal anaesthesia for Caesarean section. $\mathrm{Br} J$ Anaesth. 1996;76:61-65

20. Squara $P$, Denjean D, Estagnasie $P$ et al. - Noninvasive cardiac output monitoring (NICOM): a clinical validation. Intensive Care Med, 2007;33:11911194.
Resumen: Doherty A, Ohashi Y, Downey K, Carvalho JCA - Monitorización No Invasiva con Base en la Biorreactancia Revela Inestabilidad Hemodinámica Significativa Durante la Cesárea por Elegibilidad bajo Raquianestesia.

Justificativa y objetivos: La monitorización de la presión arterial ofrece una comprensión limitada de las consecuencias hemodinámicas de la raquianestesia para la cesárea. El objetivo de este estudio fue evaluar, con la ayuda del monitor de débito cardíaco no invasivo y con base en la biorreactancia, las alteraciones hemodinámicas durante la cesárea electiva bajo raquianestesia, en la cual bolos intermitentes de fenilefrina fueron utilizados para prevenir y tratar la hipotensión.

Métodos: Este estudio observacional fue realizado posterior a la aprobación de la comisión de ética en investigación y de la firma del consentimiento informado. Se evaluaron los pacientes sanos con cesárea electiva programada bajo raquianestesia. Bolos intermitentes de fenilefrina fueron administrados para mantener la presión arterial sistólica en los niveles basales, y las pacientes fueron evaluadas con la ayuda del monitor de débito cardíaco no invasivo con base en la biorreactancia. Los datos hemodinámicos se recopilaron continuamente en el momento basal y durante los períodos postraquianestesia y después del nacimiento del feto. Los datos se analizaron usando ANOVA para modelos mixtos, y un $p<0,05$ fue considerado significativo.

Resultados: La presión arterial sistólica se mantuvo entre 79,2 (14,2) y $105,9(10,0)$ por ciento de los valores basales durante el período postraquianestesia, y $78,4(11,13)$ y $100,9(10,7)$ por ciento de los valores basales en el período postparto promedio \pm de. Las fluctuaciones significativas se observaron en la presión arterial sistólica, en la frecuencia cardíaca y en el débito cardíaco en el período postparto.

Conclusiones: Un nuevo monitor no invasivo, con base en la biorreactancia, reveló fluctuaciones hemodinámicas significativas durante la cesárea bajo la raquianestesia, pese a los intentos de mantener la presión arterial a niveles basales con bolos intermitentes de fenilefrina.

Descriptores: ANESTESIA, Obstétrica, Regional: raquianestesia; CIRUGÍA, Cesárea; COMPLICACIONES: Hemodinâmica; TÉCNICAS DE MEDICION, débito cardíaco.

Ayuda Financiera: El equipamiento para el estudio fue suministrado por la Cheetah Medical Inc. No hubo una involucración de la compañía en la planificación del estudio, en la interpretación de los datos o en la preparación del manuscrito. 